\title{
Incitement to Hatred or Enmity and Infringement on the Liberty of Conscience and Religions: Differentiation Criteria
}

Alexei Aleksandrovich Shirshov

Far Eastern Federal University, Vladivostok, Russia

Doi:10.5901/mjss.2015.v6n6s3p233

\begin{abstract}
The present paper conducts an analysis of the standards of Russian criminal legislation establishing criminal consideration for the violation of a right for the liberty of conscience and religions, and also standards providing responsibility for hooliganism and incitement to hatred or enmity and destroying human dignity. The author discloses the contents of dispositions of the relevant criminal provisions, analyzes the standards of Russian legislation which are blanket with respect to criminal standards; considers key elements of the corpus delicti of crimes which are an object of the research; points out criteria which allow to differentiate penal provisions and to resolve an issue concerning competition of the analyzed the corpus delicti of crimes. Moreover, the author analyzes tendencies of the change of criminal legislation providing responsibility for the violation of a right for the liberty of conscience and religions, and also standards providing responsibility for hooliganism and incitement to hatred or enmity and humiliation of human dignity. The paper critically analyzes an ambiguously estimated by experts approach of a Russian legislator to criminal legal protection of the specified legal relationship analyzes potentially possible issues of law enforcement, considers internal contradictions of the criminal law in this part and problems of its ratio with the standards of the Constitution and international legislation.
\end{abstract}

Keywords: criminal responsibility, incitement to hatred; enmity, liberty of conscience, criminal policy, Pussy Riot.

\section{Introduction}

Official mass media in Russia constantly say about the need for spiritual, moral, ethical and religious revival. The power thinks that this process is started and is going, though slowly and difficult because the Russian society should overcome not only the negative religious attitudes inspired by the power in masses in days of the Soviet power, but also the crisis of culture, morals and spirituality in which there was a country from the moment of refusal from the previous ideology and of the beginning of radical economic reforms.

Realities have a little bit different, far from optimistic character. Ideas of tolerance, cultural and ideological diversity are for a long time known in Russia. They were the basis for the Constitution adopted in 1993 which proclaims equal rights and freedoms of a person and citizen regardless of sex, race, nationality, language, origin, financial and official status, residence, attitude to religion, beliefs, public associations membership, and also other circumstances. Developing and providing the actual realization of constitutional legal statuses, the Criminal code of Russia has included the standards providing criminal legal protection of the corresponding rights and freedoms.

However, attempts to reform criminal legislation which are taking place in recent years have introduced a significant amount of short stories which cause not only scientists' serious critical remarks who deal with criminal problems but also the whole public's ones. It must not be forgotten that modern Russia both under the constitution and actually is the secular state which is occupied by a set of the people with various traditions, beliefs, religions. Undoubtedly, in Russia there are orthodox roots which address the sources of the state creation. However, Russia as the Eurasian state with an abundance of polar cultures can exist only on one condition concerning mutual respect, tolerance including in the issues of belief.

In the author's opinion, changes of the standards of criminal legislation establishing responsibility for infringement upon freedom of speech became one more example of unreasonable expansion of criminal and legal repression and lack of conceptuality of criminal policy of modern Russia. Besides, the law enforcement doer will inevitably face the need for crimes differentiation provided by the articles 282 and 148 of the Criminal code of the Russian Federation. The present paper is an attempt to reveal and scientifically prove criteria allowing to differentiate the analyzed adjacent criminal standards. 


\section{Literature Review}

Russian criminal science paid and now pays close attention to problems of responsibility for crimes of an extremist orientation. In recent years S.V. Borisov. \& A.V. Zherebchenko (2015) wrote about incitement to hatred or enmity and humiliation of human dignity; problems of limits definition of freedom restriction of speech with means of the criminal law were analyzed by S. M. Olennikov (2013). Such authors as V.N. Arestov (1987); S. Goryainov (2005); K.G. Gorbunov (2012); A. Grachev (1986); V. Grigoryan \& V. Dmitrtiyev (2004); A. Korovikov, A. Polezhayev \& M. Saveli (2003) and others considered separate aspects of the criminal fight against terrorism and extremism in their works. However, in special literature there was no special question concerning differentiation of the corpus delicti of crimes provided by the Art. 282 and 148 of the Criminal code of the Russian Federation. Besides there are, practically no publications including a doctrinal analysis of the Art. 148 of the Criminal code of the Russian Federation.

\section{Methods and Materials}

A subject of the present research is two groups of the standards of Russian criminal legislation act: establishing responsibility for incitement to hatred or enmity and infringement on the liberty of conscience and religions in the theoretical and practical aspect.

The methodological base of the research is composed both of general scientific methods of knowledge (analysis, synthesis, generalization, induction, deduction) and private scientific methods of the research (legalistic, historical and legal, system and structural, comparative and legal, statistical, sociological).

K.G. Jung has noticed that "anybody, who tries to think honestly, must recognize inauthenticity of any metaphysical position including inauthenticity of all religions. A man must recognize nonattestant nature of all metaphysical provisions and bear with that the ability of human mind to «pull itself out of the mud by its ears» is confirmed by nothing (Jung, 1954). Exactly for this reason the author uses a legalistic method analyzing those concepts and categories which allow ambiguous interpretation from the point of view of the adherent of this or that religious faith.

\section{Results and Discussion}

\subsection{A subject of criminal legal protection}

It is to be noted that a subject of criminally legal protection of articles 282 and 148 of the Criminal code of the Russian Federation is enough close but does not coincide. The article 14 of the Constitution establishes that Russia is the secular state. No religion can be established as state or obligatory and religious associations are separated from the state and are equal in the eyes of the law. The article 28 of the Constitution says that the liberty of conscience, the liberty of religions including a right to profess individually or together with others any religion or to profess none, to choose freely, to have and extend religious and other beliefs and to act according to them is guaranteed to everyone.

The above stated standards are closely connected with one more article of the Constitution - the article 29 which establishes freedom of thought and word, forbids promotion or propaganda which provoke social, racial, national or religious hatred and enmity. The constitution also forbids promotion of social, racial, national, religious or language superiority.

These standards completely correspond to the article 18 of the International Covenant on Civil and Political Rights (The International Covenant on Civil and Political Rights. New York, 16 December, 1966) and the article 9 of the European Convention for the Protection of Human Rights and Fundamental Freedoms (The Convention for the Protection of Human Rights and Fundamental Freedoms. Rome, 4 November, 1950).

The article 282 of the Criminal code of Russia provides responsibility for incitement to hatred or enmity and humiliation of human dignity. The actions directed on incitement to hatred or enmity and humiliation of dignity of a human or a group of humans according to sex, race, nationality, language, origin, religious attitudes are penal, and any social group membership made publicly or with the use of mass media or information and telecommunication networks including the Internet. I believe that the connection of the standards of the Criminal code with standards of the Constitution is obvious and does not demand a special analysis. Defining an object of criminal encroachment, a legislator has directly specified the terms and definitions used in the Constitution.

Another conclusion follows from an analysis of the article 148 of the Criminal code which provides responsibility for the violation of a right for the liberty of conscience and religions. The current edition of the specified Article accepted on 29 June, 2013 establishes responsibility for the public actions expressing obvious disrespect to the society and made for 
insulting religious feelings of believers. The second part of the called article provides the qualified structure which forms the specified actions commission in places which are specially intended for carrying out church services, other religious practices and ceremonies. Let's pay our attention that changes to the Article 148 of the Criminal code of the Russian Federation were made within the ordinary campaign for criminal and legal repression expansion after a scandalous action of Pussy Riot. Earlier this article provided criminal liability only for actions which hinder difficulties of carrying out ceremonies by believers or the organizations activity of a religious character. The previous structure was transformed to the third part of the Article 148 of the Criminal law providing responsibility for illegal hindrance of the religious organizations activity or carrying out church services, other religious practices and ceremonies.

An analysis of the contents of the Article 148 allows making a conclusion on discrepancy of an object of criminal legal protection, specified in the name of the article, to an object defined in terms of its contents. It is conventional that the liberty of conscience includes not only a right to practice any religion but also a right to practice no religion including a right to be an atheist. The Criminal law protects only feelings of believers. Obviously, a legislator for any unclear reason considers that feelings of the persons who are practicing no religion do not have the need for criminal legal protection creating, on the one hand, by a believer certain preferences (benefit without specifying a concrete faith), and on the other hand - discriminating the atheists.

Obviously, an object of criminal encroachment which is protected by the Article 282 of the Criminal law is broader than an object provided by the Art. 148. Objects of the specified articles correspond as general and private: the Art. 148 is a special case of incitement to hatred or enmity by insulting feelings of believers. Moreover, a public order is an additional object provided by the Art. 148 because a legislator speaks about the actions insulting feelings of believers and expressing obvious disrespect to the society.

Thus, in terms of qualification general rules, in case of norms competition a special norm which, besides, includes an additional object in the form of a public order will mainly applied.

\subsection{Incitement to hatred or enmity and insulting feelings of believers as elements of the objective party}

Objective elements of the corpuses delicti of crimes provided by the Art. 282 and 148 of the Criminal code of the Russian Federation have much in common.

Dispositions of the Article 282 of the Criminal code of the Russian Federation specifies that an objective part of crime includes two types of acts: a) the actions directed on incitement to hatred or enmity; b) the actions directed on humiliation of dignity of a human or a group of humans.

Let's pay our attention to that circumstance that a legislator designing the specified criminal standard of the law has used not a descriptive but simple disposition without having exposed the contents of the term "incitement to hatred or enmity". The received lack was met by the supreme judicial authority. Generalizing the jurisprudence on criminal cases on crimes of the extremist orientation, the Supreme Court of the Russian Federation has explained that, in particular, by the actions directed on incitement to hatred or enmity are necessary to understand the statements proving and (or) approving the need for genocide, mass repressions, deportations, commission of other illegal actions including the violence application concerning representatives of any nation, race, adherents of this or that religion and other groups of humans (The Decision of the Plenum of the Supreme Court of the Russian Federation of 28.06.2011 №11 "On the jurisprudence practice on criminal cases on crimes of the extremist orientation").

Is it possible to consider a given above definition exhaustive? It is thought that it is impossible. The position of the Supreme Court connecting incitement to hatred or enmity with the statements proving the need for illegal actions commission with respect to representatives of any nation, race, adherents of this or that religion and other groups of humans is vulnerable. A circle of the actions exciting hatred or enmity can be much wider. For example, it is necessary to refer the formation of a negative image of the nation, race, religion or a certain social group, non-recognition by them the ability to have the rights equal to the rights of other subjects, promotion of ideas of racial, religious or other inferiority.

The Criminal law establishes a ban on humiliation of dignity of a human or a group of humans according to any social group membership. Unfortunately, the Supreme Court did not make an explanation what must be considered as a social group. The definition of the contents of the specified term is of great importance because the existing criminal code in a large number of the article of a Special part uses in the design of the qualified corpuses delicti of crimes the instruction on commission of crime based on political, ideological, racial, national or religious hatred or enmity or based on hatred or enmity concerning any social group.

The author believes that the use by a legislator of the term "a social group" allows to qualify under the Article 282 the actions directed on humiliation of any social groups regardless of their political, economic or ideological signs allowing to refer these or those people separate social groups. 
To signs of a social group the special literature refers: existence of the internal organization; existence of the common (group) target of the activity; the group forms of the social control; the models of the group activity; intensive group interactions; a feeling of group accessory or membership; the role participation of members of a group in the general activity coordinated with each other or partnership; role expectations of members of group relatively each other. (Petrovsky A.V., 1986). However, the sign of collective subjectivity - a social group is a collective subject of the social action (the social activity) the result of which is the social changes and the system creation of multilevel social communications and relations with the other subjects (social groups, organizations, communities, institutes) (Zhuravlev A.L., 2009.) has the greatest importance in the analyzed context.

Exactly the last sign, in our opinion, is the Criminal code of the Russian Federation constituting for understanding of social group essence in the context of the Article 282.

In terms of the analysis of a disposition of the Article 282 of the Criminal code of the Russian Federation it is clear that a legislator does not do distinctions neither between qualitative criteria of the society division into social groups nor between quantitative criteria providing equal legal protection to any big, small, professional social groups, to groups on et cetera interests.

It is natural that the sign of the attitudes to any faith can be easily the basis for specific social groups allocation. Thus, believers in general and believers of the concrete faiths represent the social groups which interests are a subject to criminal legal protection according to the Article 282 of the Criminal code of the Russian Federation.

Characterizing an objective part of crime provided by the $1^{\text {st }}$ part of the Art. 148 of the Criminal code of the Russian Federation, a legislator used the concept "insulting feelings of believers". Let's notice that this term is not new to Russian criminal legislation: it was already used in the Criminal code from 1993 to 1996. In that SFSP CC there was the $2^{\text {nd }}$ part of the Art. 143 which the corpus in many respects was similar to the current edition of the $2^{\text {nd }}$ part of the Art. 148 of the Criminal code of the Russian Federation. The only essential difference of the Article from the SFSP CC was that in its contents the use of mass media was specially provided as a qualifying sign while now it is not any more required.

A legislator also as well as in the Article 282 of the Criminal code of the Russian Federation did not follow the path of the descriptive disposition designing giving the law enforcement doer an opportunity to explain the term "insulting" though the term "insulting" in itself is not new to the Criminal code of Russia. The Article 130 of the Criminal code of the Russian Federation provided criminal liability for insulting and was operating from the moment of the Criminal code adoption in 1996 up to abrogation in 2011. The specified Article defined insulting as humiliation of honor and dignity of other human expressed in the indecent form. Thus, as an object of insulting honor and dignity of a human was selfassessment of a personality. Any person can be the victim. Insulting was expressed in humiliation, derogation of selfrespect of the victim. The SFSP Plenum of the Supreme Court in the item 14 of the Decision of 25 September, 1979 has emphasized that insulting represents the negative assessment of victim's identity having a generalized character.

It is obvious that given above characteristics are quite applicable when determining feelings of believers insulting.

Insulting can be caused in various ways. Oral or written insulting is expressed in the verbal form, insulting in the form of drawings, caricatures, sculptural images is also possible (for example, a person was called a pig or he was depicted combining the lines of his personality and the body of an animal). At last, it is possible to present insulting as an action - gesture or striking (for example, slaps in the face).

The characteristic of the form of humiliation of human dignity attracts much attention - it must be indecent. If the words used at the negative assessment of victim's identity are decent, standard then the corpus of insulting will not be because the law cannot forbid any critical statements.

The main difficulty in the solution of the issue concerning insulting actions of a human consists in what form of humiliation of human dignity is decent and what is not. The answer to it sends us to the moral categories. The form contradicting the conventional rules of the treatment between people is indecent. It is obvious that disputes and disagreements are in this regard inevitable.

However, in relation to the context of the Art. 148 of the Criminal code it is necessary to notice that a legislator speaks not about insulting of believers but about insulting of feelings of believers. Unfortunately, the similar formulation opens the widest opportunities for abuses for the simple reason: perception of insulting by the victim is on the first place. It is natural when a believer does not consider actions of a person as humiliating, insulting of his feelings will not be. However, what is otherwise to be done when there is hypersensibility of a person who can consider any actions as offensive for belief which are in conflict with the developed confessional rules and canons?

On cases of insulting the courts were mainly resorting to the help of philologists and appointing the literary examination which had the question whether this word is literary (common). Certainly, all obscene expressions are indecent (earlier they were also called unprintable, but recently, unfortunately, they began being published). The issue consists in whether the concrete words are offensive, and it is difficult not just for a person but for a believer's person. 
The answer to this question is not included into philologists' competence because it refers to knowledge not in the sphere of literary criticism, but in the field of religious ethics. It is natural that the final assessment of the form as indecent is given by the court, but it is not always unambiguous.

Another problem consists in that a legislator demands the assessment of acceptability or unacceptability of these or those forms not from the point of view of the average secular, non-religious person, but from the point of view of a believer's person. And in this situation a criterion of acceptability is in many respects dependent on concrete religious feelings which, in turn, depend on believer's belonging to the concrete faith. Thus, it is easy to imagine a situation when certain actions are not offensive, for example, for Muslims, and, on the contrary, will offend orthodox Christians' feelings. Moreover, in certain cases the order of religious practices departure by believers of certain faith can hurt feelings of believers of the other faiths. For example, sacrifices which are carried out in Muslim communities for Kurban Bairam's holiday often caused extremely negative reaction from Christians (Novikova N., 2010).

One conditions of responsibility on the Art. 148 of the Criminal code of the Russian Federation is that circumstance that insulting feelings of believers must occur in the form of public actions expressing obvious disrespect to the society. The sign of publicity is characteristic and for the disposition of the Art. 282 of the Criminal code of the Russian Federation.

The contents of a concept "obvious disrespect to the society" is for a long time also known to the Russian Criminal law. The specified sign is constituting in the definition of the corpus delicti provided by the Art. 213 of the Criminal code of the Russian Federation "Hooliganism". By obvious disrespect to the society the law-enforcement practice understands the violation of generally recognized standards and rules of behavior dictated by a perpetrator's desire to oppose itself to people around, to show negligence to them (The Decision of the Plenum of the Supreme Court of the Russian Federation of 15.11.2007 №45 "On the jurisprudence practice on criminal cases on hooliganism and other crimes committed from hooligan motives").

And again there is the question: whether must the offender's actions express obvious and unambiguous disrespect to the society in general from the point of view of any member of this society or refer only to representatives of the certain faith or a religious group? The current legislation does not give a simple answer to it. The logic prompts that blind following to narrow confessional interests can lead to infringement of interests of the other groups of population belonging to other religious faiths or not practicing any religion.

However, the law-enforcement practice operates in other way. In this sense the criminal case is extremely indicative brought on action against the organizers of «The Forbidden Art - 2006» exhibition which was accused by orthodox of insulting of feelings of believers. In 2006 the Tagansky Court in Moscow has sided with a prosecutor and has considered that the exhibits "cynically offended a religion", the curators of the exhibition were found guilty of commission of crime provided by the Art. 282 of the Criminal code of the Russian Federation and were sentenced to large penalties. In a motivation part of the sentence the court has specified that as a result of holding the exhibition the believing citizens "underwent psycho - traumatic influence, experienced moral sufferings, their human dignity was humiliated". It, as the court says, concerned even those orthodox believers who did not see the exposition because its information was spread on the Internet and through mass media. Some exhibits were characterized by the court as "cynical insulting a religion", and idea about the exhibition organization -"criminal intention". The court has noted that the works had the obscene language (Sedykh I., 2010).

Let's pay our attention to that circumstance that at the time of the court's adjudgement Russian criminal legislation did not contain a special standard providing responsibility for insulting feelings of believers therefore the exhibition's organizers were made responsible according to the Art. 282 of the Criminal code of the Russian Federation. The sentence caused a wide public response and was subjected to sharp criticism. The Commissioner for Human Rights in the Russian Federation Vladimir Lukin has noticed that he considered the fact of judicial proceedings, concerning the organization of «The Forbidden Art-2006» exhibition, wrong. The international human rights organization "Human Rights Watch" has called the judgment "inadmissible restriction of the freedom of expression"." Condemnation of the famous human rights activist for the organization of the «sharp» exhibition on a religious subject became the evidence of the increasing atmosphere of intolerance to free expression of opinions and beliefs in Russia"- the press release of the organization has said (The sentence is pronounced to the exhibition's organizers "Be careful, religion!"? 2005). Unfortunately, to the moment of writing of the present paper the data of the complaint of the exhibition's organizers consideration to the sentence in the European Court of Human Rights are not in open access available.

The author is completely convinced that insulting is always the external manifestation of hatred or enmity. Therefore to speak about insulting feelings of believers in this context is correct: at least, a legislator should include the instruction on a special purpose which has to pursue a guilty at insulting of feelings of believers in the form of incitement to hatred or enmity. However, the similar decision disputes the existence of the Article 148 of the Criminal code in its 
current edition because such act will completely fall under the disposition of the Art. 282 of the Criminal code of the Russian Federation.

Differentiation of the corpuses delicti of crimes provided by the Article 282 and 148 of the Criminal code of the Russian Federation must be carried out in terms of the form of incitement to hatred or enmity.

\subsection{Victims}

An analysis of the text of the Art. 282 of the Criminal code of the Russian Federation allows making a conclusion that a circle of possible victims from crime provided by the specified article is indefinitely wide. Certain citizens who are confronted with incitement to hatred or enmity can refer to them. Certain citizens, citizens who are the members of a group of the persons according to sex, race, nationality, language, origin, religious attitudes, the members of any social groups can be the victims during actions directed on humiliation of dignity.

The Article 148 of the Criminal code, on the contrary, establishes a limited circle of the victims. They are believers. The Federal law "On the Freedom of Conscience and Religious Associations" note that the state interacts with religious associations. According to the law, religious groups and religious are the types of religious associations. The law determines a religious group as a voluntary association of the people professing the same religion. A group is not a separate legal entity from the point of view of the law, and certain parishioners have the whole property which is necessary for religious practices and ceremonies. A religious organization is a properly registered group consisting not less than of 10 participants and registered as a legal entity.

Let's pay our attention to that circumstance that besides insulting religious feelings the $3^{\text {rd }}$ part of the Art. 148 of the Criminal code of the Russian Federation also provides responsibility for an obstruction to the work of religious organizations or carrying out of ceremonies and ceremonies. Thus, the law says only about an obstruction to the activity of religious organizations without providing directly responsibility for hindrance of religious groups' activity. Moreover, drawing an analogy it is obvious that only feelings of those believers which are united in the forms of religious associations provided by the law are subject to criminal legal protection. The issue concerning the reasons of this selectivity in protection of feelings of believers of a legislator and also what is to be done with feelings of those believers which did not receive an official status will be free-answer.

To sum up I will notice that a special, specific status of the victim as believer is one more criterion of differentiation of the corpus delicti of crimes provided by the Art. 282 and 148 of the Criminal code of the Russian Federation.

\subsection{Targets of crime}

As a target such element of the subjective side of crime is obligatory in both analyzed corpuses delicti. The lack of a special purpose specified in the law causes the lack of one of the corpus delicti elements, and therefore, the lack of crime itself.

For the Article 282 a target of incitement to hatred or enmity is obligatory. Crime is committed only with direct intent and with a target to excite hatred or enmity and also to humiliate the dignity of a person or a group of the persons according to sex, race, nationality, language, origin, religious attitudes and group membership. Thus, actions directed on humiliation of dignity of a human or a group of humans have a local target - to humiliate, offend, show lameness, inferiority, unattractiveness, narrow-mindedness of people of a concrete nationality or a certain citizen.

In relation to the Article 148 of the Criminal code of the Russian Federation it is to be noticed that such qualifying sign as a target means that the actions which though are itself offensive for believers are made with a purpose to offend believers. Thus, a subject of proof must surely include proofs of that crime was committed with the direct intent. It means that a guilty must understand that circumstance that his actions will be regarded by believers as insulting and directly wish occurrence of the result in the form of insulting feelings of believers.

The author has doubt about the fact that in the conditions of the modern judicial and investigative practice the admissible proofs of existence of the direct intent in commission of the specified crimes will gather in Russia.

However, a purpose of commission of crime also is a criterion allowing carrying out differentiation of corpuses delicti of crimes provided by the Art. 282 and 148 of the Criminal code of the Russian Federation.

\section{Conclusion}

It is possible much to discuss the historical development ways of domestic statehood and the role of a religion in this development, however, in the author's opinion, it should be beard in mind: the secular state is the invention non-Russian 
and especially non-nationalist, the ideas of the secular state is «one of cornerstones of the base on which there is a building of democracy». In terms of the provisions of the Constitution and the Doctrine of the Right in the democratic state all religious faiths are the institutes of civil society, i.e. associations of citizens on the basis of common interests which is a common religion. It results in the basic, fundamental postulate: a religion, its confession or not is a matter of the private interest where the state, despite any good intentions, should not interfere. Ideally, the state regulation of religious aspects of life of the society has to be reduced to providing the guarantees of realization of the freedom of religion which means not only the right to profess any of religions but also the right to be an atheist. As the whole history of human culture testifies, spirituality is an indicator of existence of a certain hierarchy of values, purposes and senses of a personality and society existing, in it the problems relating to the highest level of the world development by a person concentrate. Identifying spirituality with religiousness, we separate a considerable part of mankind from spiritual development, narrow and impoverish a concept of spirituality (Zezeka, 2009).

Intolerance itself in relation to any religious dissidence which is free or involuntarily provoked by a Russian legislator, aspiration to find an internal enemy - these factors are the signs of totalitarian consciousness. The history knows well that any totalitarian society always starts fighting for the control over private human life.

The author is convinced that for today there are and there were no objective needs for the introduction to the Criminal code a special norm establishing responsibility for insulting feelings of believers. Insulting feelings of believers, as the work shows, could be qualified (and it was successfully qualified in practice) under the Article 282 of the Criminal code of the Russian Federation providing responsibility for incitement to hatred or enmity and also on humiliation of dignity of a human or a group of humans according to sex, race, nationality, language, origin, religious attitudes and any social group membership. The transition to a causal approach in designing of criminal precepts of the law testifies is evidence of the insufficient level of the legal equipment, the absence of an accurate concept of the development of Russian criminal legislation.

\section{Acknowledgement}

This research is conducted with the support by the Ministry of Education and Science of The Russian Federation. Public research task 29.763.2014/K.

\section{References}

Jung, C.G. (1954) The Notes ro The Tibetan Book of the Great Liberation, hg. von. W.Y. Evans-Wentz.

Arestov, V.N. (1987) Religious extremism: contents, reasons and manifestation forms, ways of overcoming / V.N. Arestov - Kharkov.

Borisov S.V. \& Zherebchenko A.V. (2015) Excitement of hatred, enmity, humiliation of human dignity: problems of criminal liability establishment and realization. Moscow.

The sentence is pronounced to the exhibition's organizers "Be careful religion!"? Retrieved September, 21, 2015, from http://www .sovacenter.ru/religion/news/education-culture/relationships/sakharov-exhibition/2005/03/d4086/

Goryainov, S. (2005) Money of terror. Who paid Beslan? Moscow.

Gorbunov, K.G. (2012) Terrorism: history and present. Social and psychological research. Moscow.

Grachev, A. (1986) Political extremism. M.

Grigoryan, V. (2004) Piratstvo, robbery and terrorism at the sea / V. Grigoryan, V. Dmitriyev. - M.: ICC "Akademkniga". pp. 224.

Zhuravlev, A.L. (2009) Collective subject: main signs, levels and psychological types//Psychological magazine. Volume 30 № 5. pp. 7280.

Zezeka, E.M. (2009) Problems of formation of spiritual and moral valuable orientations of the modern youth//Education and society. №5. http://www.jeducation.ru/5_2009/121.html.

Korovikov, A. (1990) Islamic extremism in the Arab countries Moscow.

Novikova, N. (2010) Sacrifice for Kurban Bairam has caused Moscow residents' dissatisfaction http://www.spr.ru/novosti/201210/zhertvoprinoshenie-na-kurban-bayram-vizvalo-nedovolstvo-moskvichey.html

Olennikov, S.M. (2013) Restriction of citizens' electoral rights in connection with implementation of the extremist activity//Barrister. №3.

Petrovsky, A.V. (1986) Collective//General psychology. M.

Polezhayev, A. \& Savely, M. (2003) Terrorism and anti-terrorist measures (organization, methods and means) Questions and answers. M.: Joint edition of the Ministry of Internal Affairs of Russia. pp. 160.

Polezhayev A. \& Savely, M. (2003) Terrorism and anti-terrorist measures (organization, methods and means) Questions and answers. M.: Joint edition of the Ministry of Internal Affairs of Russia.

Sedykh, I. (2007) The art exhibition's organizers were condemned for "a cynical insulting a religion". Retrieved from http://www.rb.ru/ article/organizatorov-vystavki-kartin-osudili-za-tsinichnoe-oskorblenie-religii/6482007.html. 